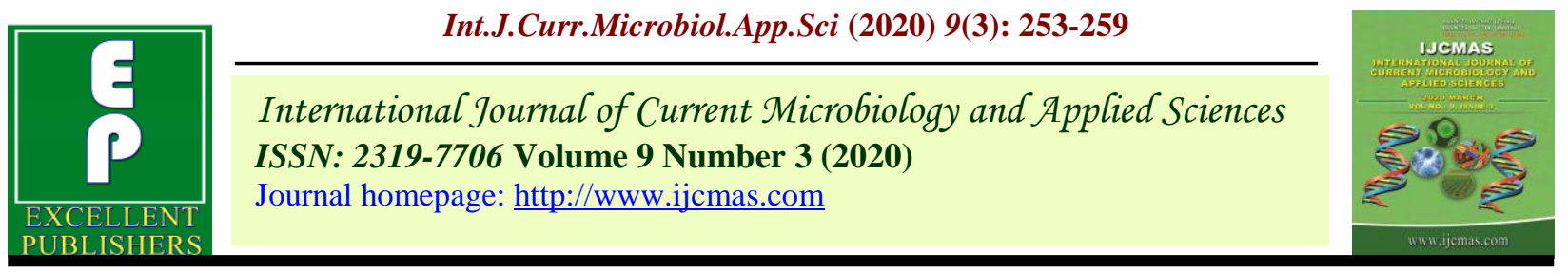

Original Research Article

https://doi.org/10.20546/ijcmas.2020.903.031

\title{
Assessment of Temperature Stress on Rice at Grain Filling Stage in Raipur District of Chattisgarh, India
}

\author{
R. K. Verma* and Mithlesh Kumar Kanwar \\ Department of genetics and plant breeding, Indira Gandhi Krishi Vishwavidyalaya, \\ Raipur (C.G), 492012, India \\ *Corresponding author
}

\begin{tabular}{|l|}
\hline Ke y w o r d s \\
Heat tolerance, \\
frequency and \\
intensity
\end{tabular}

\section{A B S T R A C T}

Rice is sensitive to high temperature, especially at the reproductive stage, which causes spikelet sterility and yield losses. The increase in both frequency and intensity of high temperature, along with its large variability, is emerging as a potential threat to the sustainability of rice production. The predicted $2-4{ }^{\circ} \mathrm{C}$ increment in temperature by the end of the 21 st Century poses a threat to rice production. The impact of high temperatures at night is more devastating than day-time or mean daily temperatures. Booting and flowering are the stages most sensitive to high temperature, which may sometimes lead to complete sterility. Recent data reveal an abnormal increase in diurnal temperatures, with night temperature increasing at a much faster rate than day temperature. To identify heat-tolerant genetic resources for future genetic studies and breeding 29 rice genotypes were screened at Raipur in the summer season (2015).

\section{Introduction}

Global warming has become one of the most complicated problems affecting agricultural productivity. It was reported that global emissions of carbon dioxide caused by human activities reached a record high in 2011 and will likely increase in succeeding years, thus contributing to the global increase in temperature (Maraseni et al., 2009; Smith and Olesen, 2010). The increase in temperature has been striking and can cause irreversible damage to plant growth and development (Wahid et al., 2007). It has been shown a 7$8 \%$ rice yield reduction for each $1{ }^{\circ} \mathrm{C}$ increase in daytime temperature from $28{ }^{\circ} \mathrm{C}$ to $34{ }^{\circ} \mathrm{C}$ (Baker et al., 1992). In future climate, it was predicted that yield of current varieties in southern Japan would reduce by up to $40 \%$ (Horie et al., 1996).

Rice with relatively higher tolerance at the vegetative stage is extremely sensitive to high temperature during the reproductive stage, 
particularly at flowering (Prasad et al., 2006; Yoshida et al., 1981; Jagadish et al., 2007, 2008, 2010a,b).

Spatial analysis using cropping pattern data from the Rice almanac (Maclean et al., 2002) showed susceptible stages of rice (i.e., flowering and early grain filling) coinciding with high-temperature conditions in Bangladesh, eastern India, southern Myanmar, and northern Thailand (Wassmann et al., 2009b).

Although the global mean temperature could increase by $2.0-4.5{ }^{\circ} \mathrm{C}$ by the end of this century, it has been predicted that minimum night temperature will increase at a much faster rate than maximum day temperature (IPCC 2007).

Rice, with its widely diverse genetic traits early-morning flowering (EMF) to escape higher temperature during the later hours of the morning (Ishimaru et al., 2010) and hightemperature avoidance through transpiration cooling (Weerakoon et al., 2008) is better equipped to withstand high day temperature, provided that sufficient water is available. However, the limited stomatal activity at night makes rice extremely vulnerable to rapidly increasing night temperature.

Further, increases in $\mathrm{CO} 2$ concentration and other climatic factors such as solar radiation and relative humidity influence the degree to which high temperature affects rice productivity. The contribution of these variables to yield variation has received less attention.

Diurnal temperature change can significantly affect rice production. Day temperatures beyond the critical level can adversely affect photosynthesis, by changing the structural organization of thylakoids and disrupting photosynthetic system II (Karim et al., 1997, Zhang et al., 2005). This will, in turn, increase the generation of reactive oxygen species, leading to the loss of cell membrane integrity, cell content leakage, and, ultimately, death of cells (Schoffl et al., 1999, Howarth 2005).

\section{Materials and Methods}

The present study was conducted at Research cum Instructional Farm, College of Agriculture, Indira Gandhi Krishi Vishwavidyalaya, Raipur Chhattisgarh, India. The experiment was conducted during Rabi (summer season) 2015.

During Rabi 2015 maximum temperature were $42.0^{\circ} \mathrm{C}$ and minimum temperature $19^{\circ} \mathrm{C}$ were recorded during crop season. The experimental material consists of 29 rice genotypes along with three checks namely $\mathrm{N}$ 22, Samleswari, IGKV R-1 and they were screened for heat tolerance under natural conditions. The 29 rice genotypes used in the present investigation and 26 rice genotype were received from the IRRI Philippines.

\section{Method}

The experiment was conducted in Randomized Block Design with three replications. The 29 rice genotypes including local checks were evaluated during summer 2015 for heat tolerance. The experimental field was divided into three blocks for heat tolerant experiments. The row-to row and plant-to-plant distance was $20 \mathrm{~cm}$ and $15 \mathrm{~cm}$, respectively. Transplanting of the material was done manually keeping single seedling per hill with 21 days old seedling. Standard fertilizer dose of $80 \mathrm{~N}: 50 \mathrm{P}: 30 \mathrm{~K} \mathrm{~kg} / \mathrm{ha}$ was applied. The entire dose of phosphorus and potassium along with half dose of nitrogen was applied as basal at the time of field preparation and the remaining nitrogen were applied in two split doses at twenty days interval in the standing crop. 


\section{Results and Discussion}

Screening of rice genotypes on the basis of spikelet fertility

The spikelet fertility is an important and useful character for evaluation of genotypes. In present study 14 rice genotypes were recorded more than $80 \%$ spikelet fertility and 13 rice genotypes sowed between $61-80 \%$ spikelet fertility and 1 rice genotypes noted 11 - $40 \%$ spikelet fertility. Among 29 rice genotypes, 27 rice genotypes found to be superior for high temperature tolerance.

The spikelet fertility is an important and useful character for evaluation of genotypes. From Table the rice genotypes were evaluated as at which temperature which genotype shows good spikelet fertility percentage by comparing the date of flowering with the maximum temperature. At 21th April, the maximum temperature is $42{ }^{\circ} \mathrm{C}$ and the spikelet fertility percentage in genotype IR $11 \mathrm{C} 114$ is $81.30 \%$.

At 20 th April, the maximum temperature is $41.3^{\circ} \mathrm{C}$ and the spikelet fertility percentage ranges from $85.77 \%$ (IR 11C128). Other genotypes IR 74099-3R-5-1 and IR 11C119 have $95.04 \%$ and $76.36 \%$ spikelet fertility percentage. At 22th April, the maximum temperature is $41.7{ }^{\circ} \mathrm{C}$ and the spikelet fertility percentage in genotype IR 72593-B3-2-3-3-2B-1 is $72.38 \%$. At 24th April, the maximum temperature is $40.5{ }^{\circ} \mathrm{C}$ and the spikelet fertility percentage in genotype IR 72046-B-R-3-2-1 and IRHTN 126 is $66.45 \%$ and 94.51, At 26 April, the maximum temperature is $37{ }^{\circ} \mathrm{C}$ and the spikelet fertility percentage in genotype IR $10 \mathrm{C} 112$ is 85.10 $\%$.

Table.1 Screening of rice genotypes on the basis of spikelet fertility

\begin{tabular}{|c|c|c|c|}
\hline SCORE & STATE & GENOTYPES & TOTAL \\
\hline 1 & $\begin{array}{c}\text { More than } \\
80 \%\end{array}$ & $\begin{array}{l}\text { IR 10C112, IR 11C114, IR 11C115, IR 11C120, IR } \\
\text { 11C128, IR 11C170, IR 65199-4B-19-1-1, IR 70868-B- } \\
\text { P-11-3, IR 70865-B-P-6-2, IR 71895-3R-26-2-1-2B-2, } \\
\text { IR 74099-3R-5-1, IR 11C173, IRHTN 126,N-22;IR } \\
\text { 10C146, }\end{array}$ & 15 \\
\hline 2 & $61-80 \%$ & $\begin{array}{l}\text { IR 11C134, IR 11C130, IR 11C126, IR 11C138, IR } \\
\text { 11C169, IR 70031-4B-R-2-2-1, IR 68144-2B-4-2-3-2, } \\
\text { IR 72046-B-R-3-2-1, IR 72593-B-3-2-3-3-2B-1, IR } \\
\text { 11C119, IR 11C127, Samleswari, IGKV-R1 }\end{array}$ & 13 \\
\hline 3 & $41-60 \%$ & IR 11C149 & 1 \\
\hline 4 & $11-40 \%$ & & 0 \\
\hline 5 & $\begin{array}{c}\text { Less than } \\
11 \%\end{array}$ & & 0 \\
\hline
\end{tabular}


Table.2 Performance of rice genotypes at maximum temperature related to spikelet fertility percentage

\begin{tabular}{|c|c|c|c|c|c|c|}
\hline S.No. & Variety & $\begin{array}{c}\text { Date of } \\
\mathbf{5 0 \%} \\
\text { flowring }\end{array}$ & $\begin{array}{c}\text { Days of } \\
\mathbf{5 0 \%} \\
\text { flowering }\end{array}$ & $\begin{array}{l}\text { Max. } \\
\text { Temp. }\end{array}$ & $\begin{array}{l}\text { Min. } \\
\text { Temp. }\end{array}$ & $\begin{array}{c}\text { Fertility } \\
\quad \%\end{array}$ \\
\hline 1. & IR $10 \mathrm{C} 112$ & $26 / 4 / 2015$ & 99 & 37 & 21 & 85.10 \\
\hline 2. & IR 10C146 & $20 / 4 / 2015$ & 93 & 41.3 & 26.8 & 82.10 \\
\hline 3. & IR $11 \mathrm{C} 114$ & $21 / 4 / 2015$ & 94 & 42 & 26.4 & 81.30 \\
\hline 4. & IR $11 \mathrm{C} 115$ & $27 / 4 / 2015$ & 100 & 36.6 & 19 & 83.33 \\
\hline 5. & IR $11 \mathrm{C} 120$ & $29 / 4 / 2015$ & 102 & 40 & 26.2 & 88.05 \\
\hline 6. & IR $11 \mathrm{C} 126$ & $6 / 5 / 2015$ & 109 & 38.6 & 24.5 & 78.57 \\
\hline 7. & IR $11 \mathrm{C} 128$ & $20 / 4 / 2015$ & 93 & 41.3 & 26.8 & 85.77 \\
\hline 8. & IR 11C130 & $1 / 5 / 2015$ & 104 & 40 & 24.3 & 79.10 \\
\hline 9. & IR 11C134 & $8 / 5 / 2015$ & 111 & 41 & 25.2 & 80 \\
\hline 10. & IR 11C138 & $4 / 5 / 2015$ & 107 & 40 & 23 & 76.93 \\
\hline 11. & IR 11C149 & $4 / 5 / 2015$ & 107 & 40 & 23 & 55.20 \\
\hline 12. & IR 11C169 & $1 / 5 / 2015$ & 104 & 40 & 24.3 & 76.15 \\
\hline 13. & IR $11 \mathrm{C} 170$ & $29 / 4 / 2015$ & 102 & 40 & 26.2 & 82.45 \\
\hline 14. & IR 65199-4B-19-1-1 & $1 / 5 / 2015$ & 104 & 40 & 24.3 & 80.45 \\
\hline 15. & IR 68144-2B-4-2-3-2 & $4 / 5 / 2015$ & 107 & 40 & 23 & 68.61 \\
\hline 16. & IR 70031-4B-R-2-2-1 & $30 / 4 / 2015$ & 103 & 41 & 27.6 & 75.23 \\
\hline 17. & IR 70865-B-P-6-2 & $28 / 4 / 2015$ & 101 & 35 & 25 & 89.62 \\
\hline 18. & IR 70868-B-P-11-3 & $1 / 5 / 2015$ & 104 & 40 & 24.3 & 84.41 \\
\hline 19. & IR 71895-3R-26-2-1-2B-2 & $27 / 4 / 2015$ & 100 & 36.6 & 19 & 86 \\
\hline 20. & IR 72046-B-R-3-2-1 & $24 / 4 / 2015$ & 97 & 40.5 & 26.2 & 66.45 \\
\hline 21. & IR 72593-B-3-2-3-3-2B-1 & $22 / 4 / 2015$ & 95 & 41.7 & 28.5 & 72.38 \\
\hline 22. & IR 74099-3R-5-1 & $20 / 4 / 2015$ & 93 & 41.3 & 26.8 & 95.04 \\
\hline 23. & IR $11 \mathrm{C} 119$ & $20 / 4 / 2015$ & 93 & 41.3 & 26.8 & 76.36 \\
\hline 24. & IR 11C127 & $2 / 5 / 2015$ & 105 & 41.8 & 28 & 76.41 \\
\hline 25. & IR $11 \mathrm{C} 173$ & $30 / 4 / 2015$ & 103 & 41 & 27.6 & 86.87 \\
\hline 26. & Poornima (LC) & $24 / 4 / 2015$ & 100 & 40.5 & 26.2 & 94.51 \\
\hline 27. & $\mathrm{~N}-22$ & $4 / 5 / 2015$ & 107 & 40 & 23 & 84.67 \\
\hline 28. & Samleshwari & $30 / 4 / 2015$ & 103 & 41 & 27.6 & 73.07 \\
\hline 29. & IGKV-R1 & $7 / 5 / 2015$ & 110 & 40 & 22.8 & 67.25 \\
\hline
\end{tabular}




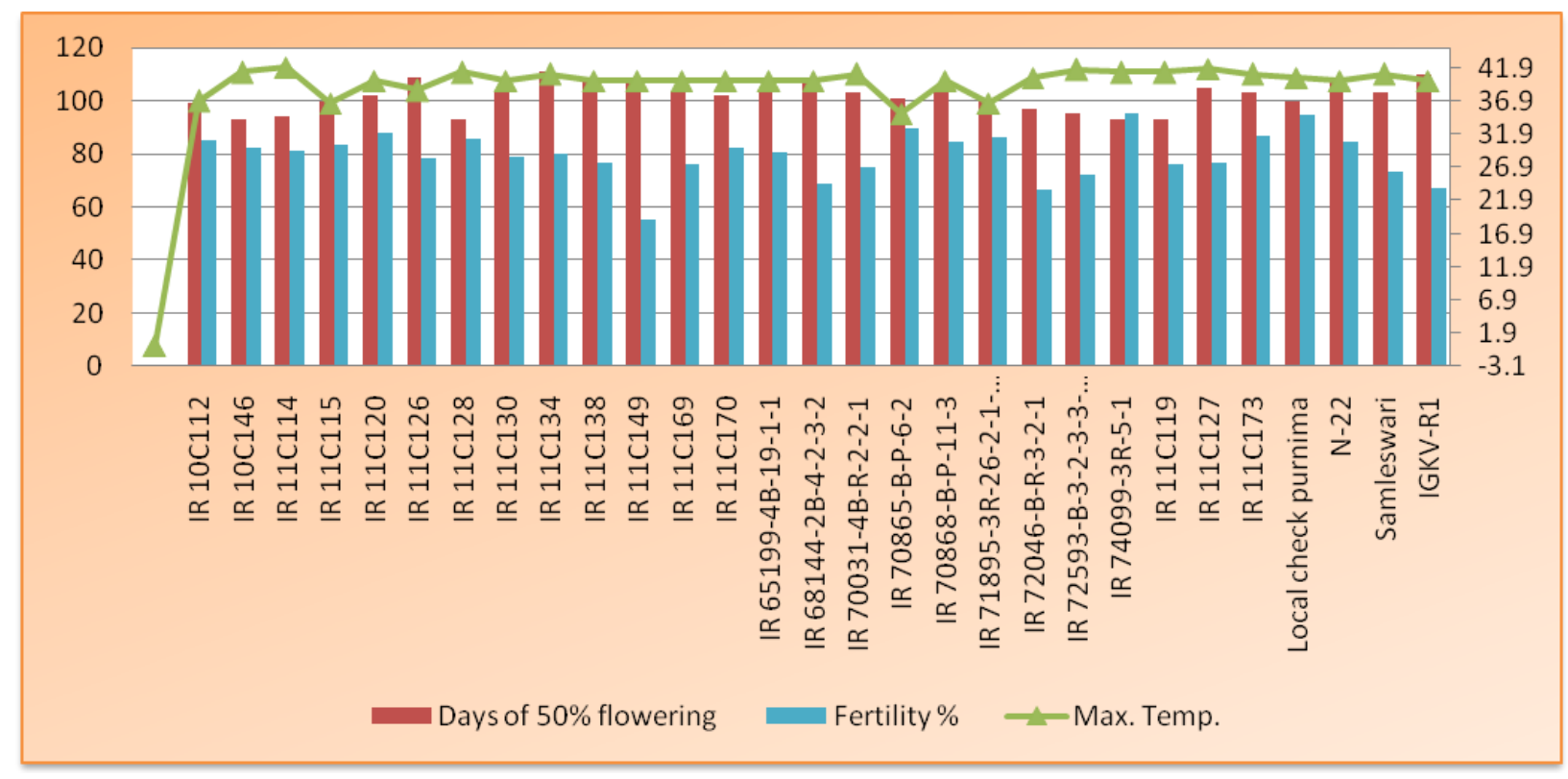

Fig.1 Performance of rice genotypes at maximum temperature related to spikelet fertility $(\%)$

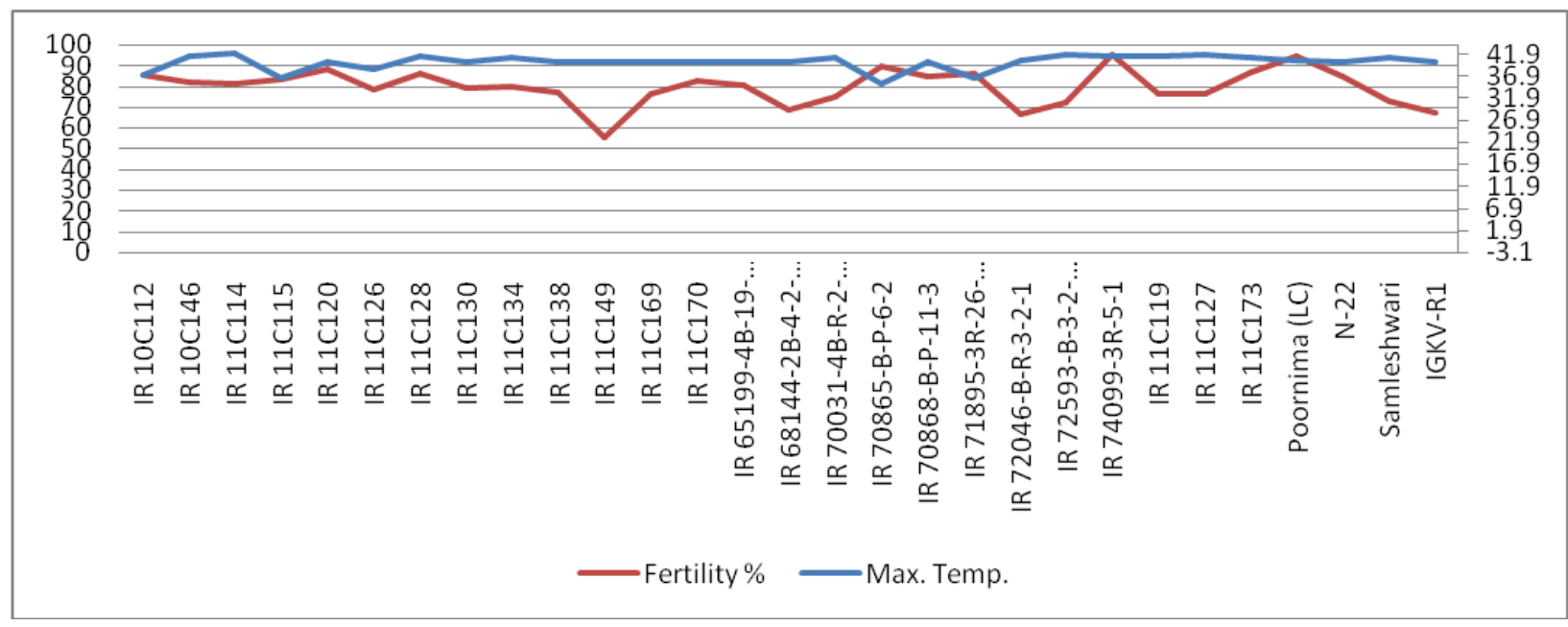

Fig.2 Performance of rice genotypes at maximum temperature related to spikelet fertility percentage

At 27th March, the maximum temperature is $36.6{ }^{\circ} \mathrm{C}$ and the spikelet fertility percentage ranges from $83.33 \%$ IR $11 \mathrm{C} 115$ to $86.0 \%$ (IR 71895-3R-26-2-1-2B-2, At 28 April the maximum temperature is $35^{\circ} \mathrm{C}$ and spikelet fertility percentage in genotype IR 70865-BP-6-2 is $89.62 \%$. At 29th April, the maximum temperature is $40{ }^{\circ} \mathrm{C}$ and the spikelet fertility percentage in IR $11 \mathrm{C} 170$ is $82.45 \%$ and IR $11 \mathrm{C} 120$ is $88.05 \%$, At 30th April, the maximum temperature is ${ }^{\circ} 41 \mathrm{C}$ and the spikelet fertility percentage ranges from $73.07 \%$ (samleswari) to $75.23 \%$ (IR 700314B-R-2-2-1).

$1^{\text {st }}$ March the maximum temperature is $40{ }^{\circ} \mathrm{C}$ and spikelet fertility percentage in IR $11 \mathrm{C} 130$ is 79.10 and IR $11 \mathrm{C} 169$ is 76.15 and two genotype IR65199-4B-19-1-1 and IR 70868B-P-11-3 fertility percentage is $80.45 \%$ and $84.41 \%$, at 2 nd march the maximum temperature is 41.8 and the spikelet fertility 
percentage in genotype IR $11 \mathrm{C} 127$ is $76.41 \%$. At 4 th march, the maximum temperature is $40{ }^{\circ} \mathrm{C}$ and the spikelet fertility for genotype IR $11 \mathrm{C} 138$ is $76.93 \%$ and genotype IR $10 \mathrm{C} 149$ is $55.20 \%$.and genotype IR $68144-2 \mathrm{~B}-4-2-3-$ 2 is $68.61 \%$,genotype $\mathrm{N}-22$ is $84.67 \%$.

At 6 th march the maximum temperature is $38.6^{\circ} \mathrm{C}$ and the fertility percentage is genotype IR $11 \mathrm{C} 126$ is $78.57 \%$, and at 7 th march the maximum temperature is $40{ }^{\circ} \mathrm{C}$ the fertility percentage is genotype IGKV-R1 is $67.25 \%$,at 8th march the maximum temperature is $41{ }^{\circ} \mathrm{C}$ and the spikelet fertility for genotype IR $11 \mathrm{C} 134$ is $80 \%$,

\section{References}

Baker JT, Allen Jr LH, Boote KJ (1992). Temperature effects on rice at elevated CO2 concentration. J. Exp. Bot. 43: 959-964.

Horie T, Matsui T, Nakagawa H, Omasa K (1996). Effect of elevated CO2 andglobal climate change on rice yield in Japan. In: Omasa K, Kai K, Taoda H, Uchijima Z, Yoshimo M, eds., Climate change and plants in east Asia. Tokyo, 39-56.

Howarth CJ. 2005. Genetic improvements of tolerance to high temperature. In: Ashraf M, Harris PJC, editors. Abiotic stresses: plant resistance through breeding and molecular approaches. New York: Howarth Press Inc. p 277300.

Ishimaru T, Hirabayashi H, Ida M, Takai T, San-Oh YA. Yoshinaga S, Ando I, Ogawa T, Kondo M. 2010. A genetic resource for early-morning flowering trait of wild rice Oryza officinalis to mitigate hightemperature-induced spikelet sterility at anthesis. Ann.Bot. doi:10.1093/aob/mcq124.

Jagadish S, Crauford PQ, Wheeler TR (2007). High temperature stress and spikelet fertility in rice (Oryza sativa L.). J. Exp Bot. 58: 1627-35.

Jagadish S, Crauford PQ, Wheeler TR (2008). Phenotyping parents ofmapping populations of rice (Oryza sativa $L$.) for heat tolerance duringanthesis. Crop Sci. 48: 1140-1146.

Jagadish S, Muthurajan R, Oane R, Wheeler T, Heuer S, Bennett J, Craufurd Q (2010). Physiological and proteomic approaches to address heat tolerance during anthesis in rice. J. Exp. Bot. 61: 143-156.

Karim MA, Fracheboud Y, Stamp P. 1997. Heat tolerance of maize with reference of some physiological characteristics. Ann. Bangladesh Agric. 7:27-33

Maraseni TN, Mushtaq S, Maroulis J (2009). Greenhouse gas emissions from rice farming inputs: a cross-country assessment. J. Agric. Sci. 147: 117-126.

Prasad PVV, Boote KJ, Allen Jr. LH, Sheehy JE, Thomas JMG (2006). Species, ecotype and cultivar differences in spikelet fertility and harvest index of rice in response to high temperature stress. Field Crops Res. 95: 398-411.

Schöffl F, Prandl R, Reindl A. 1999. Molecular responses to heat stress. In: Shinozaki K, Yamaguchi-Shinozaki K, editors. Molecular responses to cold, drought, heat and salt stress in higher plants. Austin, Texas: R.G. Landes Co. p 81-98.

Smith P, Olesen JE (2010). Synergies between the mitigation of and adaptation to climate Tenorio et al., $\mathrm{R}$. K. (2013).

Wahid A, Gelani S, Ashraf M, Foolad MR (2007). Heat tolerance in plants: an overview. Environ. Exp.Bot. 61: 199233.

Wassmann R, Jagadish SVK, Sumfleth K, Pathak H, Howell G, Ismail A, Serraj R, Redoña E, Singh RK, Heuer S (2009). Regional vulnerability of climate 
change impacts on Asian rice production and scope for adaptation. Adv. Agron. 102: 93-105

Weerakoon WMW, Maruyama A, Ohba K. 2008. Impact of humidity on temperature-induced grain sterility in rice (Oryza sativa L). J. Agron. Crop Sci. 194:135-140.
Zhang JH, Huang WD, Liu YP, Pan QH 2005. Effects of temperature acclimation pretreatment on the ultrastructure of mesophyll cells in young grape plants (Vitis vinifera L. cv. Jingxiu) under crosstemperature stresses. J. Integr. Plant Biol. 47:959970.

\section{How to cite this article:}

Verma. R. K and Mithlesh Kumar Kanwar. 2020. Assessment of Temperature Stress on Rice at Grain Filling Stage in Raipur District of Chattisgarh. Int.J.Curr.Microbiol.App.Sci. 9(03): 253-259. doi: https://doi.org/10.20546/ijcmas.2020.903.031 